\title{
Morphological changes in the cephalic salivary glands of females and males of Apis mellifera and Scaptotrigona postica (Hymenoptera, Apidae)
}

\author{
Silvana Beani Poiani* and Carminda Da Cruz-Landim \\ São Paulo State University (UNESP), Department of Biology, Institute of Biosciences Av. 24A, no.1515, Bela Vista, CEP \\ 13506-900, Rio Claro, São Paulo, Brazil \\ *Corresponding author (Fax, +55 193526 4136; Email, spoiani@yahoo.com)
}

\begin{abstract}
The cephalic salivary glands of some species of bees are exclusive and well developed only in Apinae. These glands were studied with light and scanning electron microscopy in workers, queens and males from the honey bee Apis mellifera, and the stingless bee Scaptotrigona postica in different life phases. The results show that the cephalic salivary glands are present in females of both the species, and in males of $S$. postica. Nevertheless, they are poorly developed in young males of A. mellifera. In both species, gland growth is progressive from the time of emergence to the oldest age but, in A. mellifera males, the gland degenerates with age. Scanning electron microscopy shows that the secretory units of newly emerged workers are collapsed while in older workers they are turgid. Some pits on the surface of the secretory units correspond to open intercellular spaces. The possible functions of these glands in females and males of both species are discussed.
\end{abstract}

[Poiani S B and Cruz-Landim C 2010 Morphological changes in the cephalic salivary glands of females and males of Apis mellifera and Scaptotrigona postica (Hymenoptera, Apidae); J. Biosci. 35 249-255] DOI 10.1007/s12038-010-0029-z

\section{Introduction}

Insects have a salivary gland system associated with the mouth appendices. The labial or salivary glands consist of paired glands, whose secretory portion lies in the thorax. These are connected to the tongue by the excretory ducts. In adult bees, the salivary system consists of the labial or salivary glands, mandibular and hypopharyngeal glands. In spite of being a part of the salivary system, the functions of the various glands are not always related to food ingestion or digestion.

The labial glands of bees are known as the real salivary glands, because their secretion is delivered on the tongue. This condition facilitates the immediate mixing of secretion with the ingested food.

The labial glands are homologous with the so-called salivary glands of other insects and in holometabolous insects, as in bees they originate from the larval salivary glands during post-embryonic development (Snodgrass 1956; Cruz-Landim 1967; Cruz-Landim and Mello 1967; Silva-de-Moraes 2002).

Even though the secretions of the salivary glands are delivered on the tongue, the secretory units are located in the thorax constituting the thoracic salivary glands present in all species of bees. However, in some species of bees, an additional pair of salivary glands with a common excretory duct is present in the head. This cephalic salivary gland is present in some species of Megachilinae, but with plain development and function is found only in some species of Apinae (Cruz-Landim 1967).

The cephalic salivary gland grows into the head during pupation as an outgrowth from the remains of the common excretory duct of the larval salivary gland (Cruz-Landim and Mello 1967).

The thoracic and cephalic salivary glands produce different kinds of secretions and have different functions, even though they have a common embryonic origin and excretory duct. In the Meliponini and Bombini, there is a swelling called the salivary pouch, where the ducts of the thoracic and cephalic salivary glands converge.

Studies by Simpson (1960), Simpson et al. (1968) and Delage-Darchen et al. (1979) show that the secretion of the thoracic salivary gland is an aqueous solution of digestive enzymes whereas the secretion of the cephalic gland is oily.

Keywords. Anatomy; bee; labial gland; queen; scanning electron microscopy; worker 
In general, the salivary glands of bees differ in females and males, being more developed in females. The workers perform various tasks in the colony in a sequence, according to their age and physiological state or the needs of the colony. Changes from one task to another are generally marked by changes in the development and function of the exocrine glands (Cruz-Landim 1994). Observations by Heselhaus (1922), Inglesent (1940) and Simpson (1960, 1961, 1963) suggest that the cephalic salivary glands in forager workers of $A$. mellifera are developed to a greater extent. KatzavGozansky et al. (2001) and Poiani (2007) have supported the observations by Heselhaus (1922) through statistical analysis.

Taking into account the relationship between the organ $\mathrm{s}$ morphology and its function, in the present study, the morphological and functional characteristics of the cephalic salivary glands were analysed in order to contribute to the knowledge of possible gland function. The study was performed in different life phases or colonial functions of workers, queens and males of two species of eusocial bees, Apis mellifera Linnaeus (1758) and Scaptotrigona postica Latreille (1807).

\section{Materials and methods}

\subsection{Materials}

The cephalic glands of workers, queens and males of Apis mellifera and Scaptotrigona postica were obtained. The workers were captured according to their state in the colony, i.e. when newly emerged (young), as nurses (middle-aged) and as foragers (old). Two stages of queens (virgin and egg-laying), and two stages of males (newly emerged and sexually mature) were captured.

\subsection{Methods}

2.2.1 Light microscopy: The cephalic glands were dissected in buffered saline solution for insects, spread onto histological slides and $\square$ xed with Bouin $\square$ xative. The images captured were obtained through a camera coupled to a light microscope and treated by Leica Qwin 550 Serves - Image with Peripheral Server Software.

2.2.2 Scanning electron microscopy (SEM): For the SEM studies, only workers and queens were used. The glands were dissected and $\square$ xed in Karnovsky $\square$ xative $(2 \%$ paraformaldehyde, $2.5 \%$ glutaraldehyde in $0.1 \mathrm{M}$ sodium cacodylate buffer, $\mathrm{pH}$ 7.4) for one hour. After washing in distilled water, the glands were dehydrated in a series of ethanol and through critical point drying. The glands were axed on metallic supports with adhesive tape and covered with gold with a spray Sputtering Balzer SCD 050, and examined and photographed under a Philips scanning electron microscope.

\section{Results}

\subsection{Light microscopy}

The cephalic salivary glands of both species are located in the head and consist of a pair of lateral branches of the common excretory duct of the thoracic salivary glands. Each gland consists of alveolar secretory units and ducts. The alveoli are formed by an epithelium covered by a cuticle on the luminal surface. From the alveoli, ducts emerge and converge to form the excretory duct of the gland. The excretory duct of each gland joins the common excretory duct of the thoracic salivary gland to form the main excretory duct ( $\square$ gure 1A), which delivers the secretion on the tongue (i.e. glossa prementum).

The cephalic salivary glands of $S$. postica consist of spherical or elliptical alveoli and very slender ducts. The alveoli are few and form small clumps that are dispersed in the head. The junction of the cephalic and thoracic ducts is expanded and is called the salivary pouch ( $\square$ gure $1 \mathrm{~A}$ ).

In newly emerged workers of $S$. postica, the alveoli are shrivelled ( $\square$ gure $1 \mathrm{~B})$ ), whereas in foragers and egg-laying queens, they are turgid (־gure 1A). In nurse workers and virgin queens, some alveoli are empty and shrivelled, or contain only a little secretion, while others are turgid and full of secretion ( $\square$ gure 1C).

In A. mellifera, each glandular pair possesses two branches, one located frontally and the other behind the brain. The alveoli are mainly piriform and the ducts wide and $\square$ attened ( $\square$ gure 1D, E and F).

The newly emerged workers of $A$. mellifera possess collapsed alveoli ( gure 1D), which become increasingly turgid, attaining the maximum size and turgidity in forager workers and egg-laying queens ( $\square$ gure $1 \mathrm{E}$ and $\mathrm{F}$ ).

In sexually mature males as well as females of S. postica, the cephalic salivary glands are developed ( $\square$ gure $1 \mathrm{G}$ ). In contrast, in newly emerged males of $A$. mellifera, the glands are covered by fat body cells ( $\square$ gure $1 \mathrm{H}$ ), and in sexually mature males, the glands are in a regressive state, so that practically only the excretory ducts are visible.

\subsection{Scanning electron microscopy (SEM)}

In both species, under SEM, the alveoli and ducts of newly emerged workers appear collapsed (־gure 2A and D). In nurse workers and virgin queens, the majority of the alveoli are collapsed, but some are already turgid ( $\square$ gure $2 \mathrm{~B}$ ), while in forager workers and egg-laying queens, all the alveoli are turgid ( $\square$ gure $2 \mathrm{C}, \mathrm{E}$ and $\mathrm{F}$ ). 


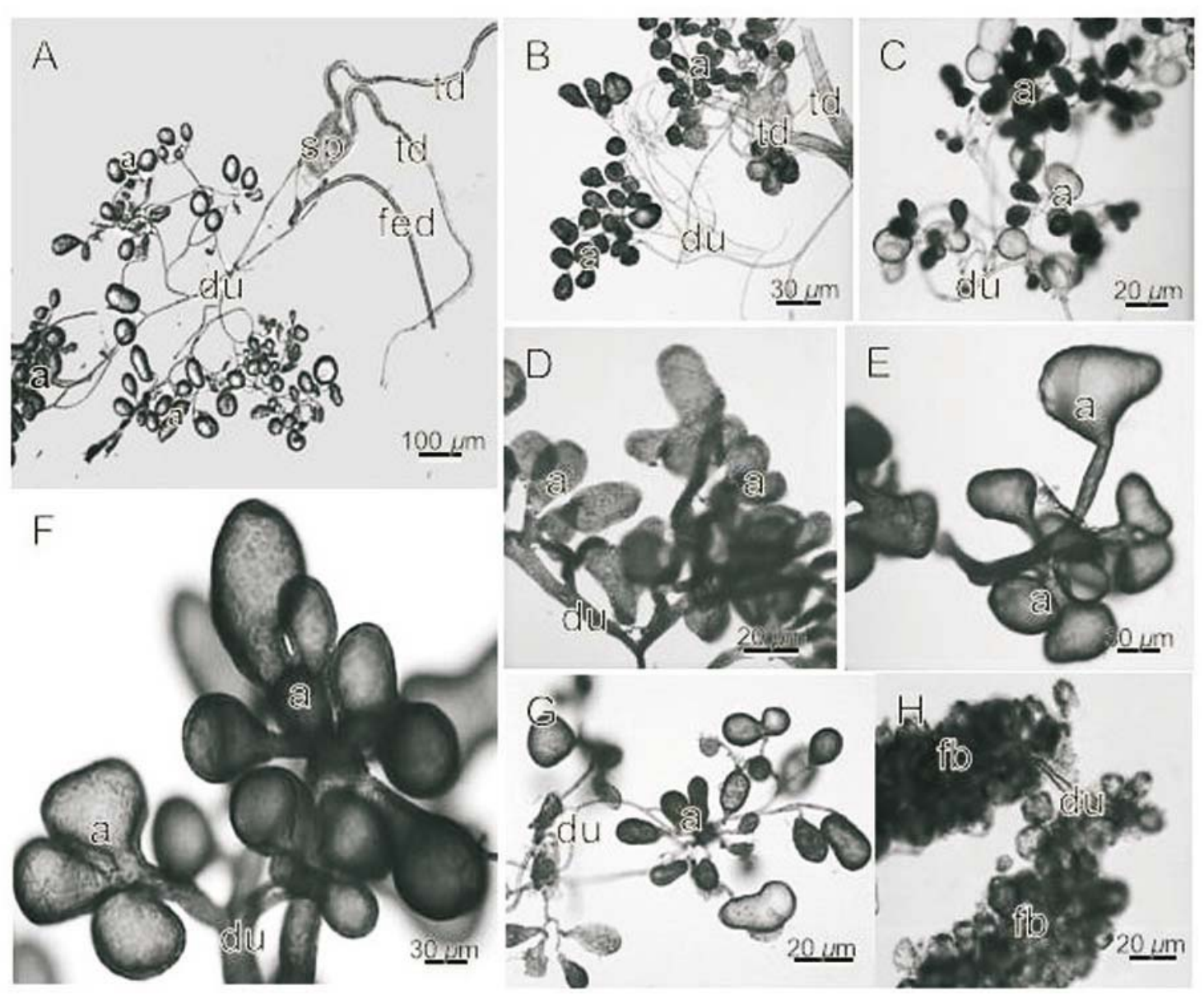

Figure 1. Light microscopy images showing the anatomical features of the cephalic salivary glands of Scaptotrigona postica and Apis mellifera. (A) General aspect of the cephalic salivary gland of an S. postica forager worker with slender ducts (du), turgid alveoli (a), a salivary pouch (sp), thoracic ducts (td), and a $\square$ nal excretory duct (fed). Newly emerged workers of S. postica (B) and A. mellifera (D) showing cephalic alveoli (a) and in A. mellifera robust $\square$ attened ducts (du). Nurse worker of $S$. postica (C) and A. mellifera (E), showing some alveoli (a) with secretion. (F) Cephalic salivary gland of egg-laying queens of $A$. mellifera with maximum accumulation of secretion, showing turgid alveoli. (G) Gland of sexually mature $S$. postica male showing the same development as a worker. (H) Newly emerged males of $A$. mellifera showing gland alveoli covered by fat body (fb).

In newly emerged workers, the limits between the alveolar and duct cells are well seen ( gure 2A), but in nurse and forager workers and in egg-laying queens, they are not visible ( gure $2 \mathrm{~B}$ and $\mathrm{C}$ ). The external surface of the alveoli and ducts of the glands of $A$. mellifera, except in newly emerged workers, possess outer pits similar to pores ( $\square$ gure $2 \mathrm{~B}$ and $\mathrm{C}$ ).

The alveoli of $S$. postica workers are mainly spherical ( $\square$ gure 2D and E), but in egg-laying queens, the alveoli are predominantly elliptical ( $\square$ gure $2 \mathrm{~F}$ ). Pits were not observed on the alveolar surface, but in egg-laying queens, the cell contours were well delineated. The excretory ducts are cylindrical and slender. In both species, the alveoli are well supplied with tracheas, as seen in $\square$ gure 2D, E and F.

\section{Discussion}

Well-developed cephalic salivary glands are seen in only eusocial species of Apinae. These, as well as the differences in secretory cycle and degree of development among the colony classes of individuals, point to the use of the secretion for activities linked to the special tasks of these individuals in society.

Bees from eusocial societies perform different tasks in the colony, which might be characterized as functional life phases. In queens there are two phases: virgin and fertilized egg-laying queens. Among workers of advanced eusocial species, the phases are characterized as a division of labour in which the different tasks are done according to worker age, characterizing a polypheny or an ethary polyethism. 

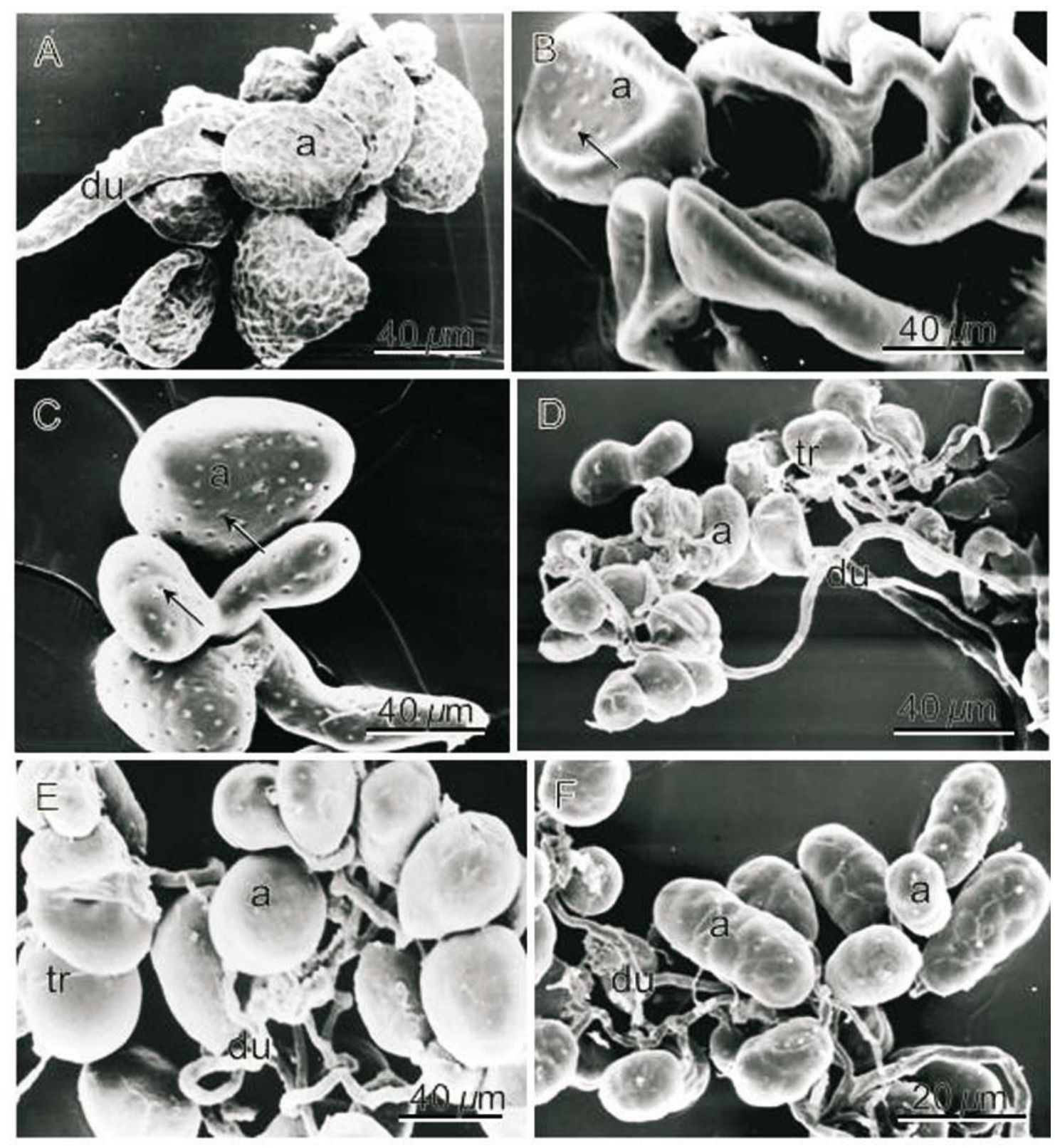

Figure 2. Scanning electron micrographs. (A) Newly emerged worker of Apis mellifera showing alveoli (a) and $\square$ attened ducts (du). The cellular limits are well seen in the alveoli and duct surface. (B) Virgin queen of $A$. mellifera with part of the alveoli turgid and part empty. (C) Turgid alveoli of several shapes in forager of A. mellifera. Surface of A. mellifera cephalic salivary gland alveoli (B and $\mathbf{C})$ and ducts marked by punctuations (arrows) that correspond to the openings of intercellular spaces. Newly emerged workers (D) and foragers (E) of Scaptotrigona postica, showing round alveoli (a) turgid in the forager and $\square$ at in the newly emerged worker. (F) Egg-laying queen of $S$. postica. Elliptical alveoli with marked cellular contours on the surfaces. a, alveoli; du, duct; tr, tracheole.

The ability of workers to display functions as required by the division of labour is closely related to the functional cycle of the exocrine glands (Michener 1974; Cruz-Landim 1994).

This paper describes the morphological differences found in the salivary glands between the species studied, and correlates the changes along the life cycle of queens and workers of the two species studied for the possible use of secretion in colonial activities.
The main differences between the species were in gland size and presence of a salivary pouch in $S$. postica. This kind of structure is also present in Euplusia violacens, Euglossa cordata, Eulaema nigrita and in some species of Bombini (Cruz-Landim 1967), but its functional signi $\sqsubset$ cance, if any, is unknown. Cruz-Landim (1967) suggested that it is a vestigial structure of the $\square$ at duct of the salivary glands of solitary bees, which do not have a cephalic salivary gland. 
Another difference between the species was the gland size or the number of secretory units per gland, i.e. the alveoli. In A. mellifera the gland is larger in size than in S. postica, even taking bee size into account, which indicate a greater capacity for production of secretion by A. mellifera. In some workers of Meliponini, branches of the cephalic salivary glands may be found in the thorax, among the tubules of the thoracic gland (Cruz-Landim 1967; Graf 1968; Silva de Moraes 1978; Cavasin-Oliveira 1995), increasing the secretory capacity of the gland. This condition was not observed in S. postica, where the secretory units of the gland were limited to the head.

The morphology of the alveoli and ducts of the cephalic salivary glands varies between the species studied and between the sexes. In A. mellifera, the alveoli are predominantly piriform, arranged in two compact masses, and the ducts are robust and $\square$ attened. In S. postica, the alveoli are spherical or elliptical, distributed in small sparse groups, and the ducts are cylindrical and slender.

In spite of these anatomical differences between the two species, the glandular cycle of activity is similar among the workers and queens of both species. Secretion accumulates in the alveoli as the individuals get older.

One characteristic found only in A. mellifera and, more speci cally, in nurse and forager workers, and in virgin and egg-laying queens, is the pitted surface of the alveoli and ducts as revealed by SEM examination. The pits correspond to the openings of the intercellular spaces in the basal, outer region of the alveoli as shown by Poiani and Cruz-Landim (2009). This feature is perceived only when the alveoli are turgid, which is a condition found in older individuals. The intercellular spaces that open to the outer environment suggest that substances from the haemolymph are allowed to enter through these spaces and eventually reach the gland lumen to be eliminated with the secretion, thus revealing that the gland has an additional excretory function. The presence of pits from the nurse phase onwards and the increase in size of the alveoli in the forager phase suggest an intensi cation of glandular activity with the age of the bee. In some insects such as the Colembola, which do not have Malpighian tubules, the salivary glands have similar characteristics and also function as excretory organs (Chapman 1998). Pits are absent in S. postica.

The continuous increase in alveolar size and turgidity from the moment of emergence to the forager phase indicates that the secretion is not used, or used only little, in intracolonial tasks. Taking into account the similarities between the cephalic salivary glands of the bee species analysed in this study and those of some species of Bombus, in which the glandular secretion is related to individual recognition (Bertsch et al. 2005; Terzo et al. 2007a, b), it is possible to suggest that the glandular secretion is used by older workers of $A$. mellifera and $S$. postica to identify individuals as belonging to a particular colony. Furthermore, the glandular secretion is used for communication regarding the location of food sources in the meliponines Trigona recursa and $T$. spinipes (Jarau et al. 2004; Schorkopf et al. 2007), to which $S$. postica is closely related. Yet, a study by Santos et al. (2009) in Plebeia emerina shows that the glandular secretion from middle-aged nurse workers is used to soften the propolis balls dispersed in the colony as a defence against invaders. In this species, the peak of glandular production occurs in middle-aged workers in contrast to the species analysed in this study. Since the gland is more developed in older workers of S. postica and A. mellifera, it is probable that the secretion could aid in the collection of resins in the eld. The same age-dependent morphology and activity of the cephalic salivary glands were found in bumblebee males (Ågren et al. 1979; ־obotník et al. 2008) and was related to the use of secretion.

In A. mellifera and S. postica, the cephalic salivary glands are similar in workers and queens. In contrast, in males, these glands are different in the two species. In $S$. postica, the glands are developed in sexually mature males as well as in females. Males of S. postica are independent of the workers care and collaborate in colony tasks (NogueiraNeto 1997). This fact may be related to the presence of developed cephalic salivary glands. Males of $A$. mellifera do not accumulate secretion since they regress with age. This condition may be related to the fact that the males of A. mellifera have a single function, namely, to fertilize the queen and, because they are fed by the workers, they do not need structures that are related to feeding (Winston 1987).

The hypothesis that the size of the cephalic salivary glands is related to their role in the life history of bees is supported by the observation that males of Bombus pomorum (Ribbands 1953), B. atratus and B. morio (Lauer 1992) have well developed cephalic salivary glands, which are sometimes larger than those of females of the same species. In Bombus, the secretion of the male cephalic salivary glands is species-speci $\square \mathrm{c}$ and produces a sexual marking pheromone ( $\square$ obotník et al. 2008). At least the males of $B$. pratorum and $B$. lapidaries demarcate their territories and attract females with the secretion of these glands (Bergman and Bergström 1997). Nevertheless, reduced cephalic salivary glands were found in the males of bumblebees of the subgenus Rhodobombus. In Rhodobombus, secretion of the reduced glands is atypical in composition and results in atypical mating behaviour (Terzo et al. 2007a, b).

As the queens are con ned to a colony and only lay eggs, it has been hypothesized that the secretion of the cephalic salivary glands must have a pheromonal function such as perhaps to identify individuals as in Bombus, which is different from the function in workers.

In conclusion, the data presented here show that glandular secretion of the same gland may have different functions in 
different species as well as within species, according to the sex and age. This supports once more the theory of functional plasticity of bee glands (Katzav-Gozansky et al. 1997, 2000).

\section{Acknowledgements}

The authors acknowledge the nancial support from Fundação de Amparo à Pesquisa do Estado de São Paulo (FAPESP), Conselho Nacional de Desenvolvimento Cientí $\llbracket$ co e Tecnológico (CNPq) and Coordenação de Aperfeiçoamento de Pessoal de Nível Superior (CAPES).

\section{References}

Ågren L, Cederberg B and Svensson B O G 1979 Changes with age in ultrastructure and pheromone content of male labial glands in some bumble bee species (Hymenoptera, Apidae); Zoon 7 1-14

Bergman P and Bergström G 1997 Scent marking, scent origin, and species speci city in male premating behavior of two Scandinavian bumblebees; J. Chem. Ecol. 23 1235-1251

Bertsch A, Schweer H, Titze A and Tanaka H 2005 Male labial gland secretions and mitochondrial DNA markers support species status of Bombus cryptarum and Bombus magnus (Hymenoptera, Apidae); Insect. Soc. 52 45-54

Cavasin-Oliveira G M 1995 Histoquímica e Ultra-Estrutura das Glândulas Salivares de Algumas Espécies de Abelhas (Hymenoptera, Apoidea) (Rio Claro, São Paulo: Tese de Doutorado, Unesp)

Chapman R F 1998 The insects: structure and function, 4th edition (London: English Universities)

Cruz-Landim C 1967 Estudo Comparativo de Algumas Glândulas das Abelhas (Hymenoptera, Apoidea) e Respectivas Implicações Evolutivas; Arq. Zool. 15 177-290

Cruz-Landim C 1994 Polimor smo na Ocorrência de Glândulas Exócrinas nas Abelhas (Hymenoptera, Apoidea); Anais do Encontro Sobre Abelhas 1 118-129

Cruz-Landim C and Mello M L S 1967 The post-embryonic changes in Melipona quadrifasciata anthidioides Lep. (Hymenoptera, Apoidea). II. Development of the salivary glands system; J. Morphol. 123 481-502

Delage-Darchen B, Tabec S and Darchen R 1979 Secretion Enzymatique des Glandes Salivaires et de L'Intestin Moyen d'une Abeille Sans Dard, Apotrigona nebulata (Sur.) (Hyménoptères, Apidés); Ann. Sci. Nat. Zool. Biol. Anim. 13 261-267

Graf V 1968 Observações sôbre o canal salivar cefálico de alguns Apidae; Bolet, Univ. Fed. Paraná (Zoologia III) 3 65-78

Heselhaus F 1922 Die Hautchüsen der Apiden und Verwandter formen; Zool. Jahrb. Jena Abt. J. Anat. 43 363-464

Inglesent H 1940 Zymotic function of the pharingeal and thoracic and post-cerebral glands of Apis mellifera; J. Biochem. 34 $1415-1418$

Jarau S, Hancir M, Zucchi R and Barth F G 2004 A stingless bee uses labial gland secretions for scent trail communication
(Trigona recursa Smith, 1863); J. Comp. Physiol.: (A Neuroethology, Sensory, Neural and Behavioral Physiology) 190 233-239

Katzav-Gozansky T, Soroker V and Hefetz A 1997 Plasticity of caste-speci $\square$ Dufour $\$ gland secretion in the honey bee (Apis mellifera L.); Naturwissenschaften 84 238-241

Katzav-Gozansky T, Soroker V and Hefetz A 2000 Plasticity in caste-related exocrine secretion biosynthesis in the honey bee (Apis mellifera); J. Insect Physiol. 46 993-998

Katzav-Gozansky T, Soroker V, Ionescu A, Robinson G E and Hefetz A 2001 Task-related chemical analysis of labial gland volatile secretion in worker honeybees (Apis mellifera ligustica); J. Chem. Ecol. 27 919-926

Lauer S M S 1992 Estrutura Macro e Microscópica das Glândulas do Sistema salivar nas Castas de Bombus atratus Franklin. (Hymenoptera, Apidae); in Pesquisas com Abelhas no Brasil (eds) A E E Soares and D D Jong (Ribeirão Preto: Revista Brasileira de Genética) pp 237-238

Michener C D 1974 The social behavior of bees: a comparative study (Cambridge, Massachusetts: The Belknap Press)

Nogueira-Neto P 1997 Vida e Criação das Abelhas Sem Ferrão (São Paulo: Nogueirapis)

Poiani S B 2007 Anatomia, histologia, histoquímica e ultraestrutura das glândulas salivares cefálicas de abelhas eussociais (Hymenoptera, Apidae), Dissertação de Mestrado, Universidade Estadual Paulista - UNESP - Rio Claro, São Paulo, Brazil

Poiani S B and Cruz-Landim C 2009 Cephalic salivary gland ultrastructure of worker and queen eusocial bees (Hymenoptera, Apidae); Anim. Biol. 59 299-311

Ribbands C R 1953 The behavior and social life of the honeybees (London: Bee Resesrch Association)

Santos C G, Megiolaro F, Serrão J E and Blochtein B 2009 Morphology of the head salivary and intramandibular glands of the stingless bee Plebeia emerina (Friese) (Hymenoptera, Meliponini) workers associated with propolis; Ann. Entomol. Soc. Am. 102 137-143

Schorcopf D L P, Jarau S, Francke W, Twele R, Zucchi R, Hrncir M, Schmidt V M, Ayasse M and Barth F G 2007 Spitting out information: Trigona bees deposit saliva to signal resource locations; Proc. R. Soc. London B. 274 895-898

Silva de Moraes R L M 1978 Variações de conteúdo de DNA e Volume Nucleares nas Glândulas Salivares de Operárias de Melipona quadrifasciata anthidioides Lep. Durante a Diferenciação Pós-Embrionária e Ciclo Secretor; Papéis Avulsos Zool. 31 251-281

Silva de Moraes R L M 2002 Glândulas Salivares do Adulto; in Glândulas Exócrinas das Abelhas (eds) C Cruz-Landim and F C Abdalla (Ribeirão Preto: FUNPEC - RP) pp 51-70

Simpson J 1960 The functions of the salivary glands of Apis mellifera; J. Insect Physiol. 4 107-121

Simpson J 1961 The salivary glands of Apis mellifera and their signi $\square$ cance in caste determination; Proc. Symp. Genet. Biol. Ital. 10 173-188

Simpson J 1963 The source of the salivary honeybees use to moisten materials they chew with their mandibles; J. Apic. Res. 2 115-116

Simpson J, Riedel I B M and Wilding N 1968 Invertase in the hypopharyngeal gland of the honeybee; J. Apic. Res. 7 29-36 
¿obotník J, Kalinová B, Cahlíková L, Weyda F, Ptá ek V and Valterová I 2008 Age-dependent changes in structure and function of the male labial gland in Bombus terrestris; J. Insect Physiol. 54 204-214

Snodgrass R E 1956 Anatomy of the honey bee (New York: VailBallow Press)

Terzo M, Coppens P, Valterová I, Toubeau G and Rasmont P 2007a Reduced cephalic labial glands in the male bumblebees of the subgenus Rhodobombus Dalla Torre (Hymenoptera: Apidae: Bombus Latreille); Ann. Soc. Entomol. 43 497-503

Terzo M, Valterová I and Rasmont P 2007b Atypical secretions of the male cephalic salivary glands in bumblebees: the case of Bombus (Rhodobombus) mesomelas Gerstaecker (Hymenoptera, Apidae); Chem. Biodivers. 4 1466-1470

Winston M L 1987 The biology of the honey bee (London: Harvard University Press)

MS received 3 December 2008; accepted 12 March 2010

ePublication: 30 March 2010

Corresponding editor: Dominique G HoMBERGER 